\title{
PRIORITISING MAINTENANCE IMPROVEMENT OPPORTUNITIES IN PHYSICAL ASSET MANAGEMENT
}

\author{
H. von Petersdorff ${ }^{1} \&$ P.J . Vlok ${ }^{2 *}$ \\ Department of Industrial Engineering \\ Stellenbosch University, South Africa \\ 1hagen. petersdorff@llamasoft.com, 2pjvlok@sun.ac.za
}

\begin{abstract}
ABST RACT
Physical Asset Management (PAM) initiatives suffer many barriers in implementation that can hinder their influence and sustainability. One of these barriers is the lack of buy-in from all levels in the organisation, due to a lack of understanding of the perceived benefits of PAM. Organisational alignment in a PAM project is achieved by aligning employees' views on the deficient areas in the organisation, and managing their expectations of the perceived benefits of a good application of PAM. Barriers in implementation are created, however, by the lack of a transparent method for conveying the significance of critical areas in the system and by an unclear way of communicating these problems. Typically these initiatives are constrained by available resources. In order for PAM initiatives to be successful, there first needs to be an alignment in the execution through a clear understanding of which assets are critical, so that resources can be allocated effectively. In this study, this problem is thoroughly examined, and a method is sought that seeks to isolate the effects of the maintenance function in an operation and to uncover critical areas. A study is performed on the methods that are typically used to create such understanding. This study highlights the shortcomings of these methods, which limit their applicability. A new methodology is therefore created in order to overcome these problems. The methodology is validated through a case study, where it shown to be highly beneficial in uncovering critical areas and achieving organisational alignment through the communication of results.
\end{abstract}

\section{OPSOMMING}

Fisiese batebestuursinisiatiewe het verskeie implementeringstekortkominge wat hulle invloed en volhoubaarheid verhinder. Een van hierdie hindernisse is die gebrek aan ondersteuning van alle vlakke in die organisasie. Dit is as gevolg van ' $n$ gebrekkige begrip van die voordele van batebestuur. Organisatoriese belyning by ' $n$ batebestuursprojek word bereik deur almal te belyn oor wat die gebrekkige areas is, en om hulle verwagtinge oor die voordele te bestuur. Metodes om op 'n deursigtige wyse die kritieke areas aan te dui en te kommunikeer, ontbreek. Dít belemmer die uitvoer van projekte en die afwesigheid van empiriese bewyse van probleme, skep ' $\mathrm{n}$ afhanklikheid van argumentatiewe menings wat dikwels verskil. Inisiatiewe word dikwels beperk deur die beskikbaarheid van hulpbronne, en 'n effektiewe toedeling van beskikbare hulpbronne is dus noodsaaklik. Om 'n suksesvolle batebestuursproj ek dus uit te voer, moet daar eers 'n duidelike begrip en ooreenstemming wees oor wat die verskeie kritieke areas is wat die meeste aandag verlang, sodat hulpbronne doeltreffend toegeken kan word. In dié studie word hierdie probleem ondersoek deur oplossings na te vors. ' $\mathrm{n}$ Metode is gesoek wat daarop gemik is om die gevolge van batebestuur te isoleer in 'n produksiestelsel en kritiese areas te ontbloot. ' $n$ Studie is uitgevoer op metodes wat gebruik word om sodanige analises uit te voer. Dit word gewys dat huidige metodes tekortkominge het wat die toepaslikheid beperk. ' $n$ Nuwe metode is geskep wat gebruik maak van simulasie om hierdie probleme te oorkom. Die metode is gevalideer deur ' $n$ gevallestudie, waar dit bevestig is dat die metode voordelig is om kritiese areas te ontbloot en om organisatoriese belyning te bewerkstellig deur effektiewe kommunikasie van die resultate.

\footnotetext{
* Corresponding author
} 


\section{$1 \quad$ INTRODUCTION}

The purpose of Physical Asset Management (PAM) is to ensure the optimised mix of cost, risk, and performance over an asset's entire life-cycle, thus ensuring that the organisation derives the maximum value possible from its physical assets. In asset-centric organisations that is, organisations that have a performance dependency on the management of their physical assets in terms of revenue generation - the management of physical assets is seen as a core competency in deriving value for the organisation.

Maintenance, defined as the act of 'causing to continue', is a dynamic service activity that seeks to maximise the availability of machinery. Maintenance has undergone a paradigm shift in recent decades, from a more reactive mindset where interventions are only called for when a component has failed, to a more proactive mindset where advanced modelling and condition monitoring tools attempt to calculate the optimum maintenance interval or threshold. This mindset shift means that maintenance is viewed as a function that is integral to production and engineering, rather than a satellite department that only receives attention when things go wrong.

PAS-55 is the current standards framework for the PAM industry. It was created in 2004 by the Institute for Asset Management, together with the British Standards Organisation and other collaborating organisations, as a standard specification for the optimised management of physical assets and infrastructure. A vital facet of asset management, according to PAS-55 [1], is that it is constructed on accurate data and information. An accurate description of the status quo is required, so that informed decisions can be made about the prioritisation of improvement opportunities.

In complex manufacturing and processing systems, it may difficult to gain an understanding of the impact of per-machine downtime on a system's output, as there are counteracting factors such as buffers and feedback loops that can dampen or exacerbate the effects of a failure. Prioritising asset care decisions without considering the system in which the asset operates, or without providing the same level of care for all assets regardless of their situation, may therefore result in wasted effort.

A typical production environment will experience a limitation in resources, such as time, money, and personnel; therefore a necessary step in an effective PAM maintenance optimisation plan is to prioritise the available interventions and to focus on the factors that will bring the greatest benefit to the organisation.

From these considerations, it was clear that a method is needed to isolate the effects of reliability-related constraints, so that their effects can be determined and the results used to direct efforts in the most effective manner.

\section{MAINTENANCE PRIORITISATION METHODS IN PRACTICE}

The idea behind criticality analysis is to identify the 'vital few' factors that have the greatest impact on the operations at the plant. The purpose of prioritising is to differentiate these important factors from the rest, so that special focus can be given to improving them. Indeed, if too many factors are equally important in the eyes of management, none receive adequate focus.

Prioritisation of interventions is usually performed, if at all, by some function that compares and ranks available actions based on a function of their benefits, costs, and risk. The most widely-used tools in industry focus on ranking potentially detrimental situations by risk; their aim is thus to avoid negative situations from occurring. Taking a positive viewpoint and assessing assets by how their availability contributes to the company's bottom line requires more complex modelling, which accounts for the attribution of value to the costs that are avoided as a result of maintenance. 
It has been well-established by PAS-55 [1], Mitchell [2], and ISO 55000 [3] that there is both a need and a desire for quantitative decision-making in PAM and in management in general. Moreover, there is a need for these techniques to be accessible to employees and simple to apply on an operational level, in order to provide sustained support for PAM decisionmaking. A thorough review was performed to discuss the various techniques that are currently being used in practice. They were evaluated on the following criteria:

- Systems-based: The selected method should view the system in its entirety and consider the complex interactions between the machines and other internal and external factors.

- Accessible: The selected method should be able to communicate the problem in a manner that is understandable by plant management. The benefit gained from the method should be somewhat proportionate to the effort required to execute the analysis. Ideally, a flexible approach is sought, where any required level of abstraction is obtainable.

- Objective: The analysis should be based on objective information and real-world data as far as possible, and should be validated by an appropriate empirical method.

- Quantitative: A vital facet of the analysis should be to aid plant managers in budgeting by attributing costs to improved maintenance practices.

As with many operations improvement projects, PAM maintenance opportunities are often selected using Pareto analysis, by focusing on the resource with the most unscheduled downtime [4]. The logic of this approach is fairly straightforward, in that the resource experiencing the most unscheduled downtime is assumed to present the biggest potential to the system for improvement. However, due to complex system interactions and constraints, this is unlikely to paint the entire picture and may result in wasted effort.

The techniques investigated in this study were all identified as potential candidates that address some or all of the stated requirements, with varying degrees of adequacy and complexity. Some of the techniques may seem to be poor choices, as they clearly fail to comply with certain requirements; however, the most effective solution was sought with regard to potential benefit for induced effort. A broad range of techniques was considered. Some analytical methods take a hard approach and seek accuracy, while others, for example the theory of constraints (TOC) of Goldratt et al. [5], take a softer approach and are more philosophical in nature. Most of the techniques are well-established in the literature and in practice, though perhaps for different roles from those that they fulfil here. A summary of the findings for each technique is presented in Table 1.

Table 1: Comparison of available prioritisation techniques

\begin{tabular}{l|l|l}
\hline Method & Description & Applicability \\
\hline Markov Chains & $\begin{array}{l}\text { Parts of the system can be modelled } \\
\text { separately, or the entire system can } \\
\text { be modelled to a simple level of } \\
\text { abstraction. }\end{array}$ & $\begin{array}{l}\text { Modelling approach is too complex. Simple } \\
\text { approaches are inadequate. }\end{array}$ \\
\hline $\begin{array}{l}\text { Theory of } \\
\text { Constraints (TOC) }\end{array}$ & $\begin{array}{l}\text { System components are prioritised } \\
\text { according to throughput rate. } \\
\text { 'Bottleneck' component receives } \\
\text { greatest attention until bottleneck } \\
\text { shifts. }\end{array}$ & $\begin{array}{l}\text { Simple approach. Good for continuous } \\
\text { improvement. Easy identification of bottleneck } \\
\text { in a linear system. Complex system components } \\
\text { (feedback loops and buffers) difficult to assess. } \\
\text { Not quantitative. }\end{array}$ \\
$\begin{array}{l}\text { Failure Mode and } \\
\text { (FMEA) }\end{array}$ & $\begin{array}{l}\text { Prioritises system components } \\
\text { according to their perceived impact } \\
\text { of failure. }\end{array}$ & $\begin{array}{l}\text { Complexity can range considerably depending } \\
\text { on detail. Tends to be subjective. Only pseudo- } \\
\text { quantitative, due to subjectivity. } \\
\text { Weibull analysis }\end{array}$ \\
$\begin{array}{l}\text { Uses historical data to determine } \\
\text { failure characteristics and failure } \\
\text { trends of components. }\end{array}$ & $\begin{array}{l}\text { Not system-orientated, so ranking can be } \\
\text { misguided. Relies heavily on accurate historical } \\
\text { data. }\end{array}$ \\
\hline Simulation & $\begin{array}{l}\text { Mathematical emulation of real- } \\
\text { world system using best possible } \\
\text { historical data and modelling insight. }\end{array}$ & $\begin{array}{l}\text { Level of complexity can be adjusted. Multi- } \\
\text { purpose evaluation. Depends on availability of } \\
\text { historical data. }\end{array}$ \\
\hline
\end{tabular}


Markov chains have been used to model reliability in industrial systems by Abboud [6], Chan and Asgapoor [7], and Dimitrakos and Kyriakidis [8]. Failure Mode and Effects Analysis (FMEA) has been discussed in this context by Xiao et al. [9] and Bowles [10]. Mitchell [2] provides a practical overview and guide to applying FMEA.

Through a thorough investigation into current asset and maintenance prioritisation practices, it was determined that the current methods typically fail to fulfil some of the expectations set by the PAM literature and industry standards. Through deliberation on project requirements and an investigation of available modelling and prioritisation techniques, it was shown that simulation is the only method that can satisfy all the criteria adequately. A technique using plant simulation as a cornerstone and sensitivity analysis was thus created in order to overcome these shortcomings. The methodology, and the use of simulation specifically for prioritising and quantifying maintenance interventions, was not yet referenced in the literature.

\section{METHODOLOGY}

There are very few examples in the literature of where simulation has been applied specifically to maintenance prioritisation. Therefore this methodology relies on the success of other applications of simulation models. Achermann's [11] maintenance optimisation project and Kleijnen's [12] simulation for sensitivity analysis were valuable guides in this study.

Despite the choice to use simulation over the other methods investigated to form the core of the analysis, some elements of these methods may be found in this methodology. For example, the philosophy of TOC is essentially followed as bottlenecks are sought and focused on; FMEA methods are kept in mind when seeking the root causes of machine downtime after specific bottlenecks have been found; and Weibull analysis is used to determine the failure characteristics of machinery, and forms an integral part of the simulation model.

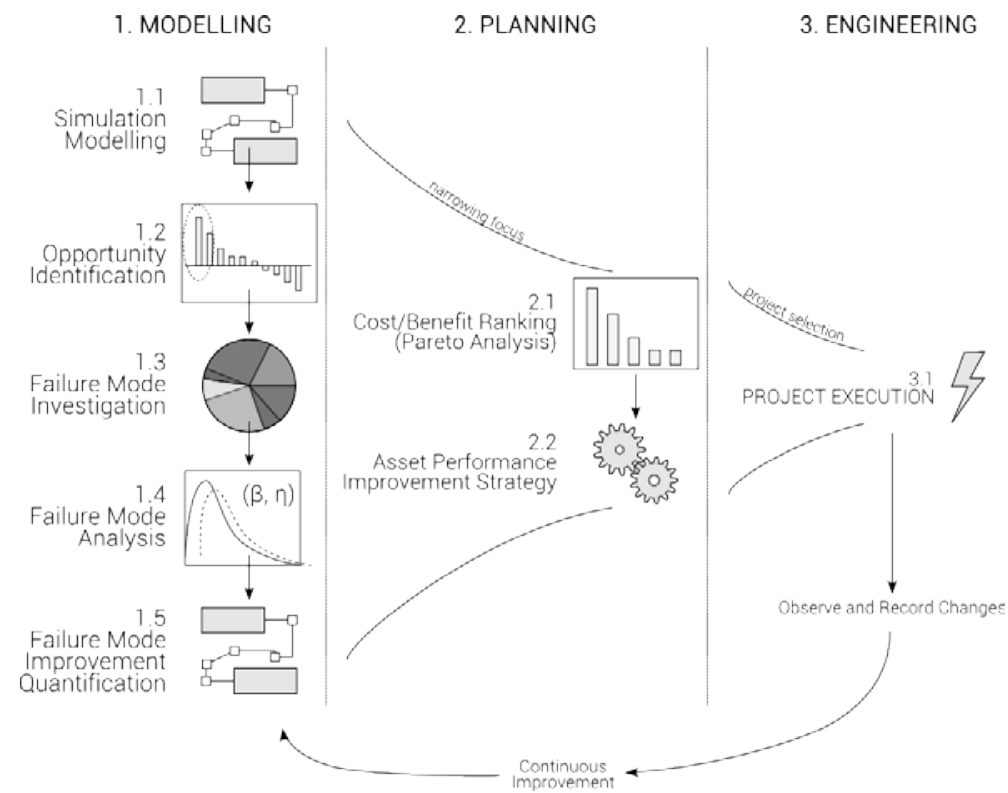

Figure 1: Steps in the proposed methodology

The execution methodology for this project is depicted in Figure 1. The corresponding items will be explained in the following sections. To be noted here is that, although the case study for this project includes only the modelling portion of the outline, the other sections have been included here and will be described in order to contextualise the project. 
Modelling: This phase details the use of modelling to represent a real world production system, and the analysis and virtual manipulation of this system using the built model. The modelling phase is the responsibility of the simulation analyst.

Simulation modelling: This stage includes all the activities required to build a simulation model, including data collection and model validation.

Opportunity identification: Once a valid model of the system has been built, a series of tests are performed in order to determine which elements in the simulation have the greatest influence on system downtime, as well as which uptime improvements yield the greatest throughput benefits.

Failure mode investigation: The opportunity identification stage will yield a list of elements, prioritised according to the system throughput benefit of uptime improvement. The strongest elements are now analysed in order to determine which failure modes cause the element to experience the most downtime.

Failure mode analysis: The simulation model data is updated, considering that the alleviation of failure modes on a machine will alter the reliability characteristics of the components of the model.

Failure mode improvement quantification: In this step, the effects of the failure mode improvement are quantified using the updated simulation model. That is, simulation analysis is performed with the updated model parameters.

Planning: The planning phase is the responsibility of plant management, or of the plant asset manager if this title exists. The modelling phase will yield a list of available maintenance interventions, prioritised according to the throughput benefit that can be attained by alleviating or eradicating failure modes. The purpose of the planning phase is to use this information to rank available interventions according to a cost/ benefit ratio, and to create maintenance plans ultimately to carry out the maintenance improvements.

Cost/benefit ranking (Pareto analysis): Management needs to determine the intervention costs for improving an element's performance. This may include performing a detailed analysis of the component in order to determine exactly what the problem is, followed by obtaining quotes from Original Equipment Manufacturers (OEMs) and otherwise determining or estimating the costs that would be incurred by improving the functioning of an element.

Asset performance improvement strategy: The output of this step is a detailed recommendation that can be passed on to engineering management. The document should include all details from the analyses performed, as well as a strategy recommendation on which actions should be performed in order to improve maintenance at the plant most effectively.

Engineering: The role of engineering is, first, to liaise with the simulation analysis project team for the purpose of model validation, and second, to carry out the asset performance improvement plans as prescribed.

Project execution: One or many projects are selected after careful consideration of the recommendations proposed by the simulation team. These projects are then executed by the engineering team.

Continuous improvement: Many aspects of this project enable it to be used in a sustainable and continuous improvement application. As certain areas of the plant improve due to focused interventions, the reliability characteristics of the plant's components can be re-examined, and the simulation periodically updated and re-run in order to observe changes to the system. Goldratt et al.'s [5] TOC may be useful in this regard. The simulation model of the plant may be re-used indefinitely, and changing the parameters in 
the model is trivial. A drawback of this approach is that sufficient time must pass in order for enough data to be generated for an updated analysis.

\section{PRIORITISATION METHODOLOGY}

An output parameter is selected to compare different scenarios. In most production systems, the most ubiquitous metric to use is system throughput, given as production units/ time, though other key performance indicators and production metrics could suffice. Sensitivity analysis is used to determine which factors in the system, when tweaked, yield the greatest potential to affect the throughput of the system positively. It is assumed that maintenance interventions will have the effect of reducing the mean time between failures (MTBF) of the machinery. Different maintenance scenarios are thus mimicked by improving the failure characteristics of the system's components and running simulations to test the effects of these tweaks. The components are thus ranked by their criticality - that is, according to their capability to affect the system.

Any model is necessarily a simplification of a real world system that enables the analyst to focus on certain aspects of a process. To this end, modelling is an art as well as a science; the simulationist must to some degree use intuition to decide which factors are most important in order to build the simplest model that still performs its function adequately.

A possible simplification of the system is a sub-grouping of certain components or functions in the production system. When looking at failures in particular, it may make sense from a modelling point of view to aggregate the failures in a particular sub-area according to what data is available. Where more detail is needed - for example, when looking at the effects of certain failure modes on a certain component - this logic can be built into the simulation. This top-down approach to simulation model building - that is, building a model and then adding detail to it - is a big advantage of object-based simulation.

Maintenance scenarios are mimicked by adjusting the MTBFs and repair durations for components. The MTBFs are adjusted incrementally and the effect on the throughput is observed. A sensitivity analysis is performed by linear least-squares regression, as the relationship between throughput and reliability is deemed linear up to a certain point of improvement. The results can then be compared using the gradients of these least-squares regression lines, as shown in Figure 2. Kleijnen [12] and Kelton and Law [13] provide further insight into the experimental design for sensitivity analysis.

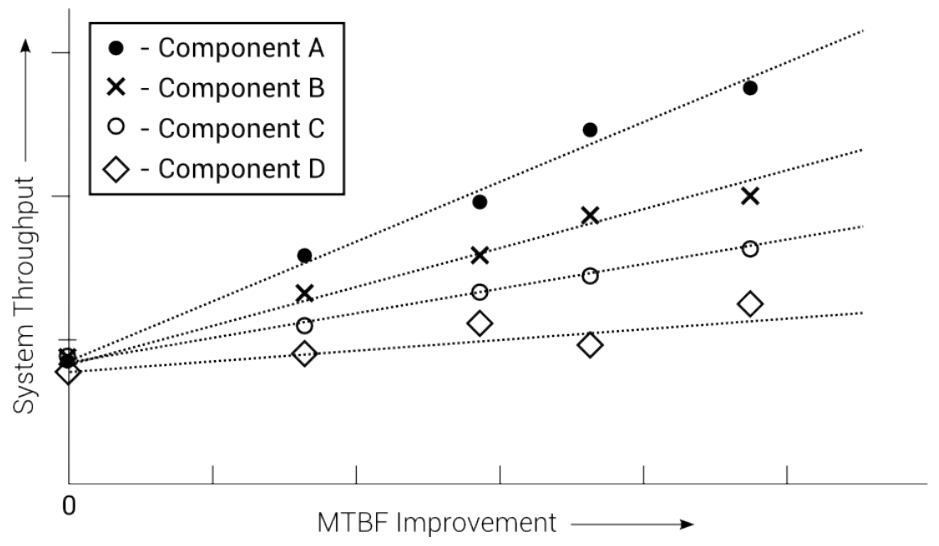

Figure 2: Visual comparison of linear regression results

Figure 3 shows how failure modes and simulation results are consolidated by using the linear regression to estimate the value of intermediate results. Using this information, the analyst may interpolate the value of any improvement to the component and if possible, compare this with the cost of performing the improvement. If the acquired dataset contains any failure mode information, the analyst may proceed with an investigation into possible 
improvement projects by analysing the failures and using the results obtained from the simulation to quantify the value of these projects. Components where improved maintenance has the greatest effect on system output will be analysed further.

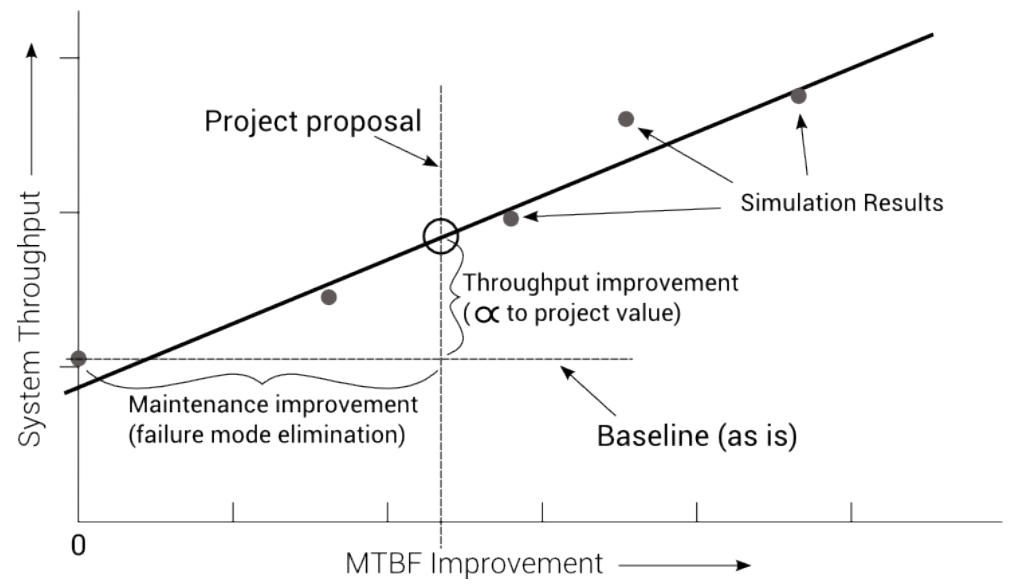

Figure 3: Consolidation of failure mode and simulation results for one component

\section{CASE STUDY}

The case study, which was performed at a large platinum ore crushing plant in Limpopo Province, South Africa, aims to validate the proposed methodology through a detailed application of the prioritisation portion of the methodology in a real-world situation with actual stakeholders. The description of the case study in this section includes data collection, data processing, model building, model simulation, interpretation of results, and prioritisation of maintenance projects.

\subsection{Field of project application}

An asset-centric environment was sought for this study, where physical assets are the primary source of revenue generation, and where asset reliability thus has a large impact on the system's output. In general it would be beneficial if the plant to be studied had, historically, been experiencing problems with reliability, as reliability improvements to such a system would have a greater effect on the output and would lead to more conclusive findings.

The availability of historical information relating to machine uptime and maintenance records is absolutely vital, as the reliability and operational data is formed from past events. Therefore, a plant with an integrated condition monitoring system that collects accurate reliability data should be selected.

An ore crushing plant of a platinum mine (hereafter referred to as an OPP) was selected to be the pilot plant for the case study, as it conformed to most of the aforementioned criteria and was willing to support the study. The following sections describe how the asset prioritisation methodology, depicted in Figure 1, was implemented at the OPP. Note, once again, that only the modelling section is dealt with in this paper, and the remaining sections provide the context of the modelling phase within a greater PAM improvement project.

\subsection{Description of operations}

In order to gain an understanding of the need for maintenance prioritisation, the operation of the plant and its current problems are discussed briefly in the following section to provide the reader with the necessary context. 
The OPP is an ore concentrating plant. This study focused on modelling the dry section of the plant. The dry section starts at the primary crusher, which receives material from the open pit mines, and ends at the primary mill, from where the ore is transferred to a floatation process. The purpose of a crushing/refining plant is to reduce the size of orecontaining rock to a fine dust so that platinum particles may be separated from the ore body by means of a chemical floatation process.

To this end, the dry section of the plant consists of a series of crushing units that use mechanical advantage to crush rocks, conveyors to transport rocks, and screens or grizzlies to sort undersized and oversized rocks at various points during the process. The secondary and tertiary crushers operate in a closed loop because, often, the ore requires multiple passes through a crusher in order to reach an acceptable diameter, after which it may exit the loop and proceed. The layout of the OPP's dry section is shown in Figure 4.

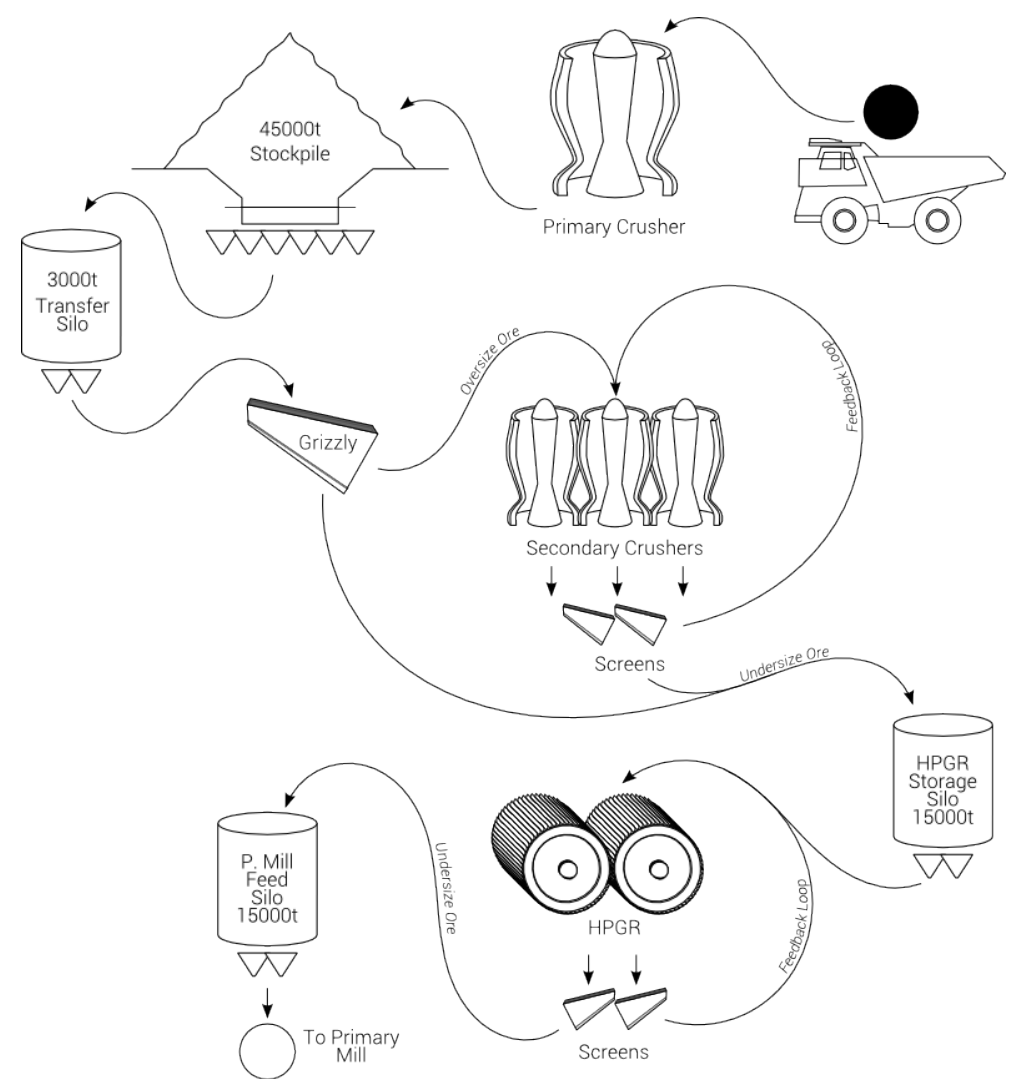

Figure 4: OPP basic plant layout

The OPP's maintenance strategy consisted of scheduled preventative maintenance with inspections at regular intervals, and a two-day maintenance period every other month during which production was halted and larger, intrusive interventions could be performed. The intrusive nature of maintenance at the OPP was somewhat offset by the large buffers present in the system. These allow for the isolation of areas in the single-stream plant so that maintenance can then be performed in these areas while other parts run unaffected provided that the outages are planned beforehand so that stockpiles can be replenished or emptied, and the maintenance task does not take too long to complete.

\subsection{Data collection process}

In order to create and validate the simulation model, data needs to be collected from the OPP. The quality and quantity of the data used is directly related to the accuracy of the 
model; therefore information that is complete and accurate is highly beneficial. The data requirements are shown in Table 2.

\section{Table 2: Data requirements for study}

\begin{tabular}{l|l}
\hline \multicolumn{1}{c|}{ Item } & \multicolumn{1}{c}{ Data required } \\
\hline Raw materials arriving from mining & Batch size, frequency \\
Throughput of each machine on the dry-line & Observed throughput, stated capacity \\
Failure data of all the machines & Frequency, downtime \\
Maintenance data for each machine & Date, unplanned/planned, time \\
Physical details of each machine & Size, throughput, buffers, etc. \\
\hline
\end{tabular}

The OPP employed a PI condition monitoring suite developed by the software company OSlsoft, which collects data on machine operating parameters in real-time data acquisition and offers a central repository for data through a facility or across multiple locations. This software made the processing of large amounts of historical data possible.

The range of data collected was for a period of approximately 13 months, from August 2011 until the middle of September 2012, al though some of this data was discarded if trend tests, as described by Vlok [14], showed that the failures were not distributed randomly, and showed increasing or decreasing rates of mortality. For each component, the most recent set failures that showed no significant trend were modelled, as these are meant to represent the 'current' operating characteristics of the plant.

For the purposes of the simulation model, the OPP dry plant under study was simplified into its core components, as shown in Figure 4, in order to reduce the complexity of the model. Failure data was available for major machinery, although downtime information for any machine was not limited to failures on that particular machine, but included any failure mode that caused that machine to cease operating. Thus some failure modes were either absorbed into or omitted from each component.

The physical characteristics of the plant's machinery were obtained from:

- Plant control narratives,

- Plant process flow diagrams,

- Plant design schematics, and

- Calculations from the recorded PI data.

All collected values were validated through interviews with plant personnel.

\subsection{Modelling failures}

The Weibull distribution was used to model failure rates as well as failure durations. The Weibull distribution, which is used often in descriptive statistics due to its flexibility, is given by:

$$
f_{x}(x)=\frac{\beta}{\eta}\left(\frac{x}{\eta}\right)^{\beta-1} \cdot \exp \left(-(x / \eta)^{\beta}\right)
$$

where $B$ is the shape and $\eta$ is the scale parameter of the distribution. $f x(x)$ provides the probability of system failure at instant $x$, exactly. The Maximum Likelihood Method was used to determine the parameters, as described by Vlok [14]. A Kolmogorov-Smirnov (K-S) test, as prescribed by Bekker [15], was performed with a significance level $p=0.05$ in order to accept or reject the proposed distributions. A visual goodness-of-fit test is shown in Figure 5 for the failure duration of Secondary Crusher 1 . The tests indicate that the Weibull distribution and its calculated parameters are indeed satisfactory for modelling the plant's failure occurrences and repair times. The results are tabulated in Table 3 and Table 4. These results, along with the system's physical characteristics, were later incorporated into the simulation model. 


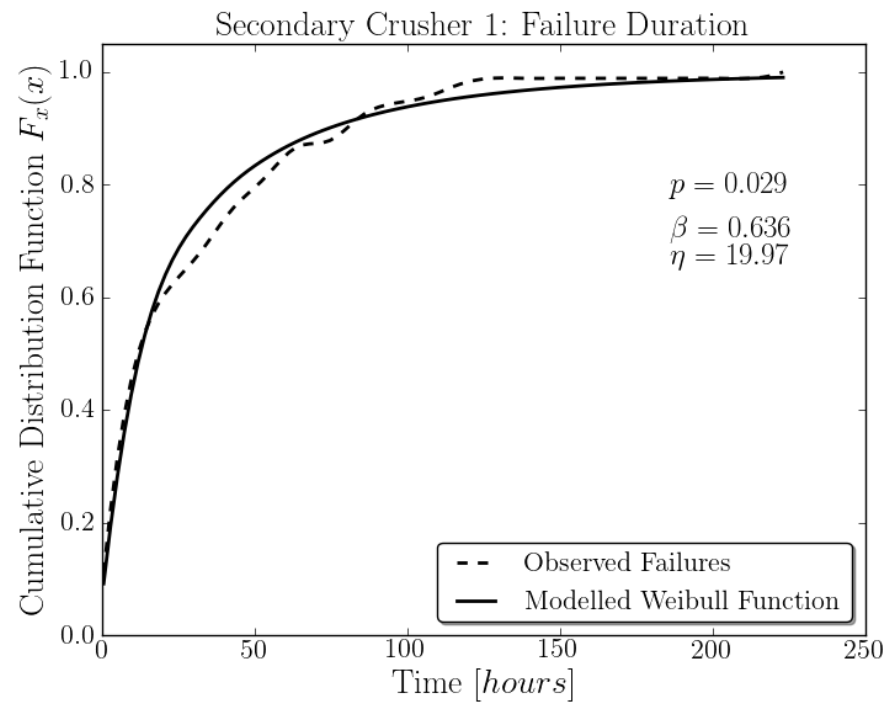

Figure 5: Goodness of fit test for Secondary Crusher 1

Table 3: Modelled mortality rates

\begin{tabular}{r|rrrrr} 
& \multicolumn{6}{|c}{ Frequency } \\
& no. failures & $\beta$ & $\eta[\mathrm{h}]$ & MTBF $[\mathrm{h}]$ & $\sigma[\mathrm{h}]$ \\
\hline Primary Crusher & 109 & $\mathbf{0 . 9 1 0}$ & $\mathbf{4 5 . 7 3}$ & 47.83 & 52.61 \\
Secondary Crusher 1 & 91 & $\mathbf{0 . 9 7 4}$ & $\mathbf{1 5 . 3 9}$ & 15.57 & 15.99 \\
Secondary Crusher 2 & 96 & $\mathbf{0 . 9 4 1}$ & $\mathbf{3 0 . 7 1}$ & 31.57 & 33.55 \\
Secondary Crusher 3 & 94 & $\mathbf{0 . 8 9 0}$ & $\mathbf{1 7 . 2 9}$ & 18.31 & 20.61 \\
HPGR & 67 & $\mathbf{0 . 9 6 5}$ & $\mathbf{2 8 . 9 9}$ & 29.45 & 30.54 \\
Primary Mill & 51 & $\mathbf{0 . 7 2 7}$ & $\mathbf{1 1 0 . 0 6}$ & 134.57 & 188.54 \\
Conveyors & 19 & $\mathbf{0 . 8 0 1}$ & $\mathbf{3 6 4 . 6 0}$ & 412.7993 & 519.76
\end{tabular}

Table 4: Modelled failure durations

\begin{tabular}{r|rrrrr} 
& \multicolumn{6}{|c}{ Duration } \\
& no. failures & $\beta$ & $\eta[\mathrm{h}]$ & MTTR $[\mathrm{h}]$ & $\sigma[\mathrm{h}]$ \\
\hline Primary Crusher & 109 & $\mathbf{0 . 5 4 6}$ & $\mathbf{1 5 . 5 2}$ & 26.72 & 53.01 \\
Secondary Crusher 1 & 91 & $\mathbf{0 . 6 3 6}$ & $\mathbf{1 9 . 9 7 2}$ & 27.97 & 45.89 \\
Secondary Crusher 2 & 96 & $\mathbf{0 . 5 7 6}$ & $\mathbf{1 6 . 0 4}$ & 25.51 & 47.23 \\
Secondary Crusher 3 & 94 & $\mathbf{0 . 6 7 5}$ & $\mathbf{2 1 . 4 0}$ & 28.08 & 42.82 \\
HPGR & 67 & $\mathbf{0 . 6 2 1}$ & $\mathbf{5 . 7 7}$ & 8.31 & 13.99 \\
Primary Mill & 51 & $\mathbf{0 . 6 4 1}$ & $\mathbf{1 3 . 4 0}$ & 18.61 & 30.21 \\
Conveyors & 19 & $\mathbf{0 . 6 4 7}$ & $\mathbf{1 2 . 0 6}$ & 16.56 & 26.55
\end{tabular}

\subsection{Translation of concept to computer model}

The simulation software used was Simio, a discrete event simulation package by Simio LLC ${ }^{1}$. Simio was first presented by Pegden [16] with the intention of simplifying models by moving away from process design and promoting the use of objects.

1 Simio LLC is a private company headquartered in Pittsburgh Pennsylvania that is dedicated to delivering leading edge solutions for the design, emulation, and scheduling of complex systems. See http:// www. simio.com/. 
The visual, object-based modelling process of Simio means that the layout and basic mechanics of a production process can be developed rapidly. The layout shown in Figure 4 was replicated in the model. Table 5 shows inputs, outputs, and parameters that were incorporated.

Table 5: Simulation model inputs, parameters, and outputs

\begin{tabular}{|c|c|c|}
\hline Model inputs & Model parameters & Model outputs \\
\hline $\begin{array}{l}\text { Ore from mine (mass } \\
\text { per load, load inter- } \\
\text { arrival times) }\end{array}$ & $\begin{array}{l}\text { Throughput rate per component in } \\
\text { tons per hour (normal distribution) } \\
\text { Failure rate distribution per } \\
\text { component (Weibull distribution) } \\
\text { Repair times per component } \\
\text { (Weibull distribution) } \\
\text { Holding capacity in tons (i.e., } \\
\text { buffer size) for buffer elements } \\
\text { (stockpile and silos) }\end{array}$ & $\begin{array}{l}\text { Mass output of primary mill output in } \\
\text { tons per simulation run, re-calculated } \\
\text { to a monthly figure }\end{array}$ \\
\hline
\end{tabular}

The simulation scenarios were set up with a one-factor-at-a-time (OFAT) sensitivity analysis in mind, as described by Pannel [17]. OFAT sensitivity analysis sequentially alters one parameter at a time while keeping all other parameters at a baseline, then returning the parameter to its baseline and repeating for each of the other inputs. The sensitivity of plant throughput, in tons of ore, was analysed against the increasing MTBF of individual plant components. The components chosen to investigate were: primary crusher, secondary crushers, High Pressure Grinding Roll (HPGR), and the primary mill. The MTBF intervals to be tested were selected at regular intervals of 20 per cent, namely at 0, 20, 40 and 60 per cent, with a regression analysis providing the linear relationship between throughput and reliability. This created three scenarios to simulate for each of the four components, and additionally a baseline case for a total of 13 simulations. A total of 120 runs of six months each, with a warm-up period of two weeks per scenario, was were performed in order to reduce the 95 per cent confidence interval half-width to approximately 2,000 tons per month for each scenario. The model created in Simio was demonstrated to plant personnel on two occasions, to confirm the validity of the process logic, layout, and operation of the plant.

\subsection{Simulation results}

The result of the sensitivity analysis is the gradient or slope of the linear regression, given in the form $y=a_{0}+a_{1} x$. For example, a gradient of $a_{1}=1,000$ is interpreted as a 1,000 tons per month increase in overall production throughput that a one percent improvement in MTBF will induce. The results are tabulated in Table 3, while Figure 6 shows a visual comparison of the results.

Table 6: Improvement Quotients Observed from Simulation

\begin{tabular}{|c|c|}
\hline Component & $\begin{array}{l}\text { al (tons per \% MTBF } \\
\text { improvement) }\end{array}$ \\
\hline $\begin{array}{l}\text { Secondary crushers } \\
\text { (SC) }\end{array}$ & 1284.3 \\
\hline Primary crusher (PC) & 243.9 \\
\hline Primary mill (PM) & 195.8 \\
\hline HPGR & 97.9 \\
\hline
\end{tabular}




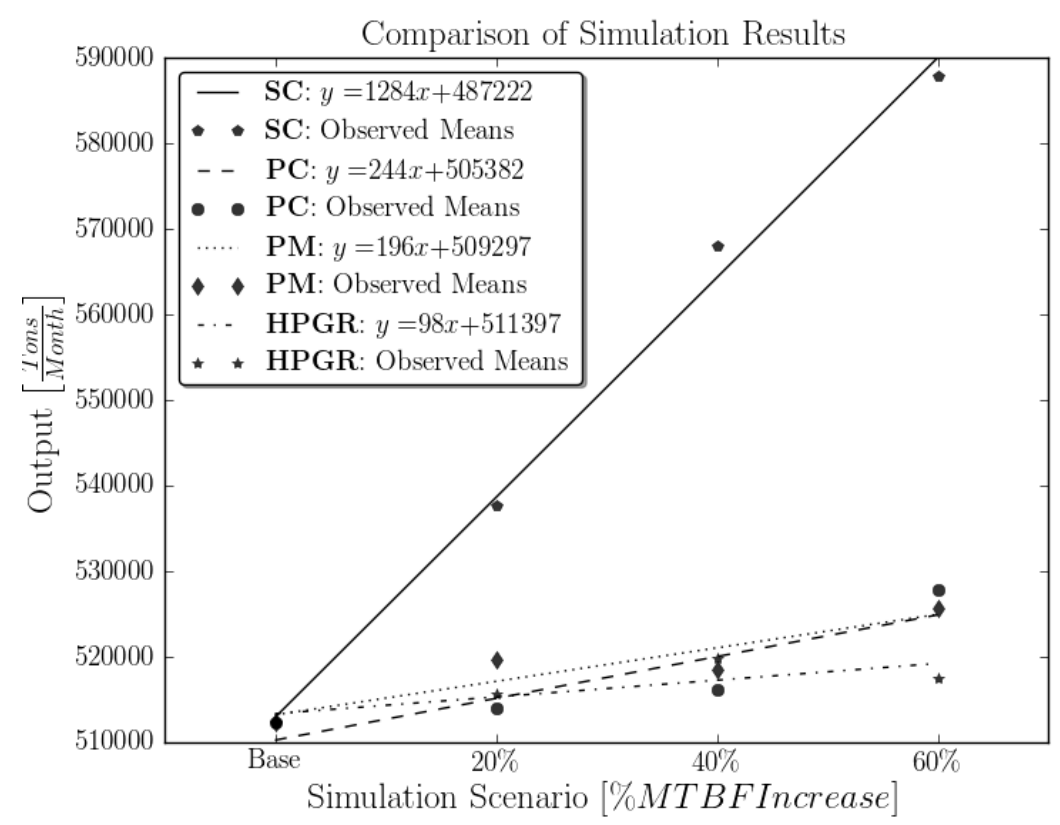

Figure 6: Comparison of linear regression results

The results of the simulation showed that the greatest opportunity for increasing plant throughput can be found by improving the reliability of the secondary crushers. The sensitivity analysis performed on the simulation scenarios showed that improvements to the reliability of the secondary crusher system caused the greatest increase in plant throughput, when compared with the other components modelled in the simulation. For every 1 per cent improvement in the secondary crushers' MTBF, a gain of 1,284.3 tons per month may be realised. The primary crusher, HPGR, and primary mill showed smaller gains of 243.9 tons per month, 195.8 tons per month, and 97.9 tons per month respectively.

This result should be interpreted as an indication that there is excess capacity downstream of the secondary crushers that they are unable to fulfill currently. By design, the secondary crushers should not be a bottleneck in the system, as they have much greater throughput than downstream systems (HPGR and primary mill). Thus a possible interpretation is that the secondary crushers have become a bottleneck in the system purely due to reliability related causes, which can be alleviated by improving PAM at the plant.

A further observation of the study is that improving any or all of the other components (primary crusher, HPGR, or primary mill) will have far smaller returns on the output of the plant, as the bottleneck clearly resides in the secondary crushers.

From these results, the conclusion can be drawn that the reliability and throughput of the secondary crushers must be aggressively monitored and improved in order to increase the monthly throughput of the OPP.

\subsection{Quantifying improvement on the secondary crushers}

A total of 208 different downtime reasons were recorded by personnel on the secondary crushers during the study period. These reasons were collated for similarity and summed, and the top ten downtime reasons, representing approximately 92 per cent of recorded downtime, were thus calculated. These results are separated into downtime resulting from a failure on any of the crushers, and downtime resulting from external factors.

The most noticeable source of downtime was the crushers' lubrication system, which accounted for $4055.6 / 16146.3=25.12$ per cent of recorded downtime, on average, for the 
crushers. Two further major sources of downtime were the removal of metal from the crushers' chutes and conveyors, and feedback faults, mainly caused by overloads and jams. This can be seen in Figure 7.

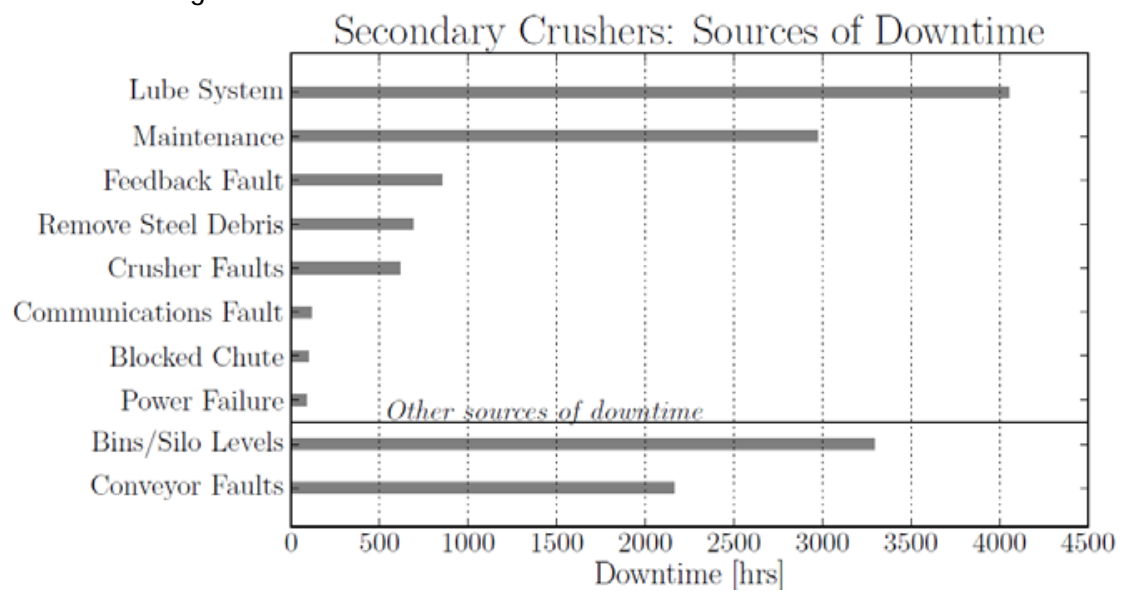

Figure 7: Sources of downtime on the secondary crushers

The crushers' lubrication system was a major source of frustration, and accounted for approximately 25 per cent of the crushers' downtime. The simulation results indicated that for every 1 per cent increase in the secondary crushers' MTBF, an overall plant throughput increase of approximately 1,284 tons per month can be expected. Eliminating this failure mode would therefore present an opportunity to increase the plant's monthly throughput by $25 * 1,284=32,100$ tons per month, a $\sim 6.36 \%$ improvement. This is demonstrated in Figure 8 .

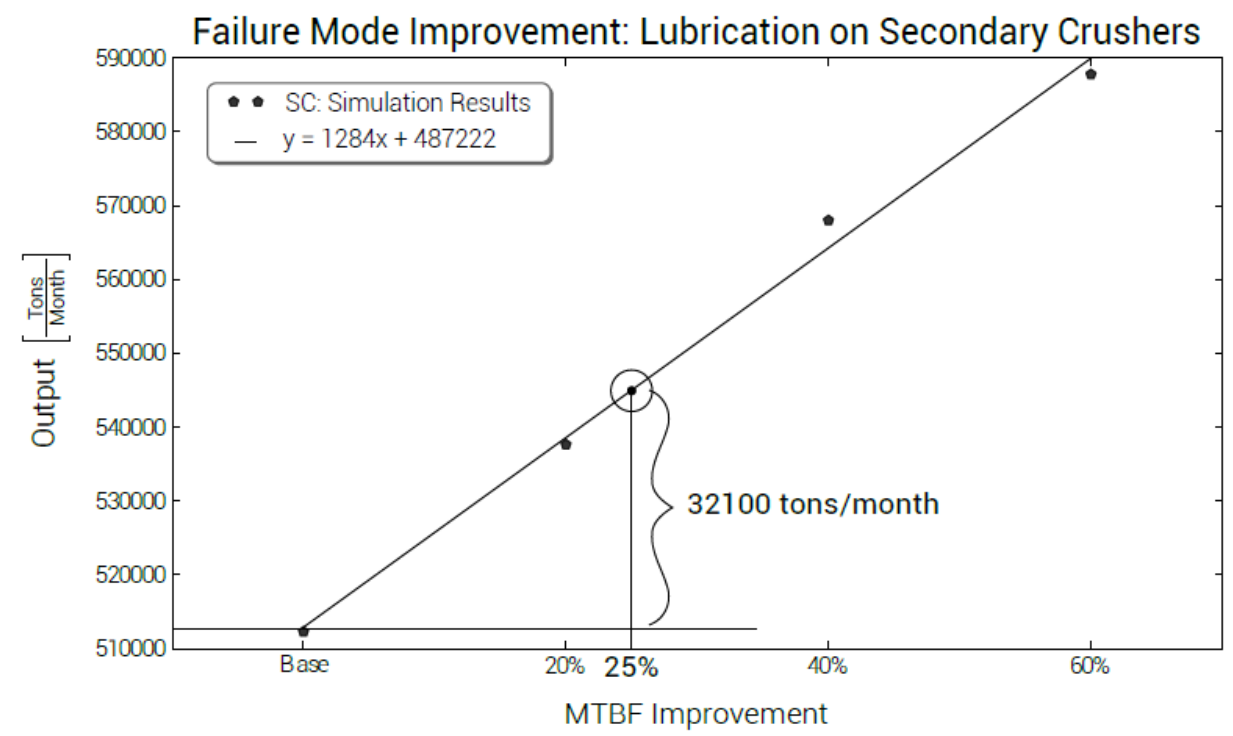

Figure 8: Quantifying the value of eliminating lubrication failures on secondary crushers

In this manner, available options can be assessed for their impact on improving plant throughput, and the most cost-effective solutions can be prioritised.

\subsection{Qualitative benefits of simulation modelling}

A vital part of this project was the validation of the simulation model, as well as being able to convince the OPP's management that the results of the model were worth investigating. 
During the multiple feedback sessions that were held at the plant, where the simulation model and the results of the simulation were demonstrated to personnel, it was found that the animation of the model was absolutely vital in gaining attention, and that this formed the main focal point of the resulting discussions. Combined with the results, it seemed that some personnel were, for the first time, forming an appreciation of what actually happens in the plant from a systems perspective, and were coming to notice the interplay between the various components in the system.

In the authors' opinion, the discussions fostered and the arguments created between the managers of the various systems were at least as valuable as the actual modelling results. When given concrete evidence of what is happening and what needs to happen in the plant, and then collectively accepting that evidence, the various minds start pulling together to form an understanding of the way forward and to move away from finger-pointing, accusatory remarks, and deflection of responsibility. These three behaviours were identified as the outcomes of meetings where the identification of problems was based only on speculation, and every manager seemed to have a different opinion. It is only when the diagnosis is accepted that the proper operation can be undertaken.

\section{CONCLUSION}

The aim of this study was to find or create a modelling approach that isolates the effects of reliability-related downtime, and prioritises and quantifies maintenance improvement opportunities in a production process. This was expanded in the problem statement, where many of the limitations of existing methods were investigated. Subsequently, a simulationbased methodology was developed, and it was determined that the selected methodology conformed to all the desired requirements. Many of the challenges that analysts typically face when building quantitative models of production systems were overcome, such as those described by Achermann [11]. These are now evaluated as follows:

- Cumbersome modelling: The transformation of the model required specialised engineering knowledge, such as knowledge of statistics, failure analysis, data analysis and programming, and being comfortable with simulation software. Beside these factors, the technique was employed rapidly and the case study could be repeated at another plant.

- Inefficient modelling techniques: Model building that uses object-oriented simulation software was efficient, and it was shown that the model could easily be tweaked in order to explore different maintenance scenarios. There was hardly any trade-off between functionality of the model and modelling efficiency.

- Limited extendibility: Models built with object-oriented simulation software are easily modified and can be used to explore different scenarios. The qualitative benefits of animating the operation of a plant and demonstrating this to personnel were also clear.

- Inadequate modelling of preventative maintenance impact on availability: The model was able to demonstrate the effects of poor maintenance (implied by poor availability) on production throughput for selected nodes in the production system.

Evidently, from the above-mentioned summary, the following can be stated:

"A modelling approach that isolates the effects of reliability-related downtime on a complex production system is a useful diagnostic tool to identify constraints and bottlenecks caused by poor PAM, and can be used as a management tool to quantify and prioritise the available improvement opportunities."

It is acknowledged that the technique has many limitations, many of which are inherited directly from the limitations of simulation. This is in line with the maxims presented by Chung [18]:

1. Simulation cannot give accurate results when input data is inaccurate; 
2. Simulation cannot provide simple answers to complex problems; and

3. Simulation alone cannot solve problems.

Readers seeking additional details should consult Von Petersdorff [19].

One of the findings of this project was the value of the simulation model, particularly the results and the animation, in fostering useful discussion among key players in management, production, and engineering. It was felt by those attending the feedback sessions that the results were invaluable as a catalyst for cross-functional conversation, with reduced fingerpointing. Thus the value of using quantitative asset contribution models to drive organisational alignment to PAM, by actively isolating the function of reliability, is a topic that should be researched further.

\section{REFERENCES}

[1] PAS-55. 2010. PAS-55: Asset management. British Standards Institute.

[2] Mitchell, J.S. 2007. Physical asset management handbook. Clarion.

[3] ISO 55000. 2013. ISO 55000. International Organisation for Standardization.

[4] Chakravorty, S.S. \& Atwater, J.B. 1994. How theory of constraints can be used to direct preventive maintenance. Industrial Management, 36(6), pp. 10-13.

[5] Goldratt, E.M., Cox, J.\& Whitford, D. 1992. The goal: a process of ongoing improvement. Volume 2, New York: North River Press New York.

[6] Abboud, N. 2001. A discrete-time Markov production-inventory model with machine breakdowns. Computers and Industrial Engineering, 39, pp. 95-107.

[7] Chan, G. \& Asgapoor, S. 2006. Optimum maintenance policy with Markov processes. Electric Power Systems Research, 76, pp. 452-456.

[8] Dimitrakos, T. \& Kyriakidis, E. 2008. A semi-Markov decision algorithm for the maintenance of a production system with buffer capacity and continuous repair times. International J ournal of Production Economics, 111, pp. 752-762.

[9] Xiao, N., Huang, H.-Z., Li, Y., He, L. \& J in, T. 2011. Multiple failure modes analysis and weighted risk priority number evaluation in FMEA. Engineering Failure Analysis, 18, pp. 11621170 .

[10] Bowles, J. 2004. An assessment of RPN prioritisation in a failure modes effects. Journal of the IEST, 47, pp. 51-56.

[11] Achermann, D. 2008. Modelling, simulation and optimisation of maintenance strategies under consideration of logistic processes. Doctoral thesis, Swiss Federal Institute of Technology, Zurich.

[12] Kleijnen, J.P. 2005. An overview of the design and analysis of simulation experiments for sensitivity analysis. European J ournal of Operational Research, 164, pp. 287-300.

[13] Kelton, W.D. and Law, A.M. 2000. Simulation modelling and analysis. Boston, MA: McGraw Hill.

[14] Vlok, P.J . 2012. Introduction to practical statistical analysis of failure time data: Long term cost optimisation and residual life estimation. Self-published.

[15] Bekker, J. 2011. Short notes on aspects of discrete event simulation (Lecture Notes). Department of Industrial Engineering, Stellenbosch University.

[16] Pegden, C.D. 2007. Simio: a new simulation system based on intelligent objects. In: Proceedings of the 39th conference on Winter simulation: 40 years! The best is yet to come. IEEE Press, pp. 2293-2300

[17] Pannell, D. 1997. Sensitivity analysis of normative economic models: Theoretical framework and practical strategies. Agricultural Economics, 16(2), pp. 139-152.

[18] Chung, C. 2003. Simulation modelling handbook: A practical approach. CRC.

[19] Von Petersdorff, H.A. 2013. Identifying and quantifying maintenance improvement opportunities in physical asset management. Master's thesis, Stellenbosch University. 